\title{
Use of phylogeny to resolve the taxonomy of the widespread and highly polymorphic African giant shrews (Crocidura olivieri group, Crocidurinae, Mammalia)
}

\author{
Sylvain Dubey ${ }^{\mathrm{a}, *}$, Maxence Antonin ${ }^{\mathrm{a}}$, Christiane Denys ${ }^{\mathrm{b}}$, Peter Vogel ${ }^{\mathrm{a}}$ \\ ${ }^{a}$ Department of Ecology and Evolution, University of Lausanne, CH-1015 Lausanne, Switzerland \\ ${ }^{\mathrm{b}}$ UMR CNRS 5202: OSEB. CP51-USM601, Département Systématique et Evolution, Musée National d'Histoire Naturelle, 55, \\ rue Buffon, F-75005 Paris, France
}

Received 20 March 2006; received in revised form 10 May 2006; accepted 19 May 2006

\begin{abstract}
The aim of this study is to provide a better understanding of the genetic relationships within the widespread and highly polymorphic group of African giant shrews (Crocidura olivieri group). We sequenced 769 base pairs (bp) of the mitochondrial cytochrome $b$ gene and $472 \mathrm{bp}$ of the mitochondrial control region over the entire geographic range from South Africa to Morocco. The analyses reveal four main clades associated with different biomes. The largest clade occurs over a range covering Northwest and Central Africa and includes samples of C. fulvastra, C. olivieri, and C. viaria. The second clade is composed of C. goliath from Gabon, while South African C. flavescens, and C. hirta form two additional clades. On the basis of these results, the validity of some taxa in the $C$. olivieri group should be reevaluated.
\end{abstract}

(C) 2006 Elsevier GmbH. All rights reserved.

Keywords: Africa; Control region; Crocidura olivieri; Cytochrome $b$

\section{Introduction}

The family Soricidae, within the order Eulipotyphla (former Insectivora), is divided into three sub-families, the Soricinae, the Myosoricinae, and the Crocidurinae, of which Crocidura is the main genus with 172 species (Hutterer 2005). The Crocidurinae have a rather tropical distribution, with, in terms of genera, a higher diversity in Africa (Quérouil et al. 2001) where its morphologybased taxonomy presents many uncertainties (Butler et al. 1989). This problem was first noted more than 15 years ago, but has remained significant until today.

*Corresponding author.

E-mail address: sylvain.dubey@unil.ch (S. Dubey).
Quérouil et al. (2005) compared molecular data in some of the problematic taxa with classical morphological assignment. The authors demonstrate that some morphologically distinguished species are not confirmed by molecular genetics and, in turn, strongly differentiated genetical clades do not correspond to morphological species.

The focus of our investigation are the African giant shrews, here named the 'Crocidura olivieri group', because of the diversity of this species within this complex, and because of its large distribution. This group was previously named the $C$. flavescens group by Heim de Balsac and Barloy (1966). Members of this group are widespread throughout Africa and express an ecological plasticity seldom achieved by other Crocidura 
species (Heim de Balsac and Aellen 1958) but found in the ecologically equivalent Asian house shrew Suncus murinus (Lekagul and McNeely 1988; Hutterer and Tranier 1990). The species of this group are adapted to a variety of habitats such as savannah, mountain, hygrophile forest, steppe, and marsh, which provide diverse habitats for the species (Heim de Balsac and Barloy 1966). The present distribution and population density are strongly influenced by anthropogenic factors. Indeed, this group is synanthropic, and its current distribution may reflect human activities as well as natural processes. This is the case in African villages, and they may even reach higher densities in towns such as Abidjan and Dakar where they seem to replace rats as the dominant urban species (Heim de Balsac and Barloy 1966).

The main morphological character regrouping taxa in the African giant shrews group is their large size. Thus, the term 'group' for the African giant shrews is not well defined by synapomorphic characters, as a large size could be due to similar selective pressure and convergent evolution. It is therefore possibly not a monophyletic clade. Consequently, it is difficult to delineate the different species and sub-species. Heim de Balsac and Barloy (1966) regrouped a variety of local forms under the name $C$. flavescens, including for example kivu, manni, nyansae, occidentalis, and sururae. According to Heim de Balsac and Barloy (1966), the name of the C. flavescens group was first assigned on the basis that within the African giant shrews, C. flavescens (Geoffroy, 1827) was the oldest available name. They considered another giant shrew described in the same year, C. olivieri (Lesson, 1827), based on embalmed shrews from ancient Egypt (Hutterer 1994), to be invalid. When an analysis of chromosomes of South African C. flavescens (Maddalena et al. 1987) showed a significant difference to $C$. olivieri from Egypt (De Hondt 1974), it turned out that C. flavescens was a separate species confined to South Africa, whereas C. olivieri is a species with a wide range, including most of the broadly distributed polymorphic giant shrews (Meylan and Vogel 1982). The conclusions based on chromosome studies were confirmed by a subsequent study of allozymes (Maddalena 1990a). As the same karyotype may include several related species (Vogel et al. 2003), the taxonomic status of these different forms remained problematic.

A particular problem concerns the black forms that were originally described as different species, $C$. odorata and $C$. giffardi, or even as a different genus, Praesorex goliath Thomas, 1913. In a synthesis, Heim de Balsac and Meester (1977), followed by Hutterer et al. (1982), concluded that the black forms must be assigned to the same species, $C$. odorata, with a wide range from Burkina Faso (BF) to the Congo. Unexpectedly, the black giffardi morph turned out to show the same karyotype as C. olivieri (Meylan and Vogel 1982), and to pool genetically with $C$. olivieri manni (Maddalena 1990a, b). However, Hutterer (1993) redefined the previously named Praesorex goliath as Crocidura goliath because it apparently represented a distinct species that lives in sympatry with $C$. olivieri in the Central African forest. Molecular data for the goliath form were interpreted accordingly (Quérouil et al. 2005).

A further chromosomal study by Vogel et al. (1988) that focussed on the Moroccan C. bolivari showed once again the same karyotype as $C$. olivieri, and the authors concluded that this form also belongs to the African giant shrews. According to Hutterer (1986), C. bolivari had to be assigned to $C$. viaria from the south of the Sahara: a shrew also called $C$. hindei and $C$. suahelae by other authors (Hutterer and Happold 1983). The synonymy of $C$. bolivari and $C$. viaria was confirmed by Maddalena (1990a).

As the study of Quérouil et al. (2005) was based on 16s rRNA, with a weak resolution, we reinvestigated the African giant shrews using two mitochondrial sequences: the cytochrome $b$ gene $(c y t-b)$ and a noncoding sequence, the control region (ctr). As mtDNA has a high degree of variability, this polymorphism has often been used in previous phylogenetic and phylogeographical studies (Fumagalli et al. 1999; Quérouil et al. 2001; Vogel et al. 2003; Fink et al. 2004).

The aim of the present study is to provide a better resolution of the relationships among the species of the C. olivieri group throughout its range in Africa and thus to increase our understanding of their phylogenetic relationship by using a comprehensive molecular analysis within this group.

\section{Materials and methods}

\section{Sampling and DNA extractions}

Eighty-two individuals of the C. olivieri group were analysed, with two $C$. poensis and one $C$. theresae chosen as outgroups. Forty-nine specimens originated from West Africa (Fig. 1), 20 from Central Africa, and 13 from Southern Africa (Fig. 1). The set of samples (Table 1) includes material from the following collections: Lausanne (IZEA), Switzerland; Paris (MNHN: Musée National d'Histoire Naturelle de Paris), France; and some specimens issued from earlier collaborations, e.g., G. Bronner (Maddalena 1990b). DNA extraction was carried out using the QIA Amp DNA Mini Kit (Qiagen) either from part of the ethanol-preserved liver or the toes of the sample.

\section{DNA amplification and sequencing}

Double-stranded DNA amplifications (PCR) of $c y t-b$ were performed with the primer pairs $231 \mathrm{~F} / 683 \mathrm{r}$ or 


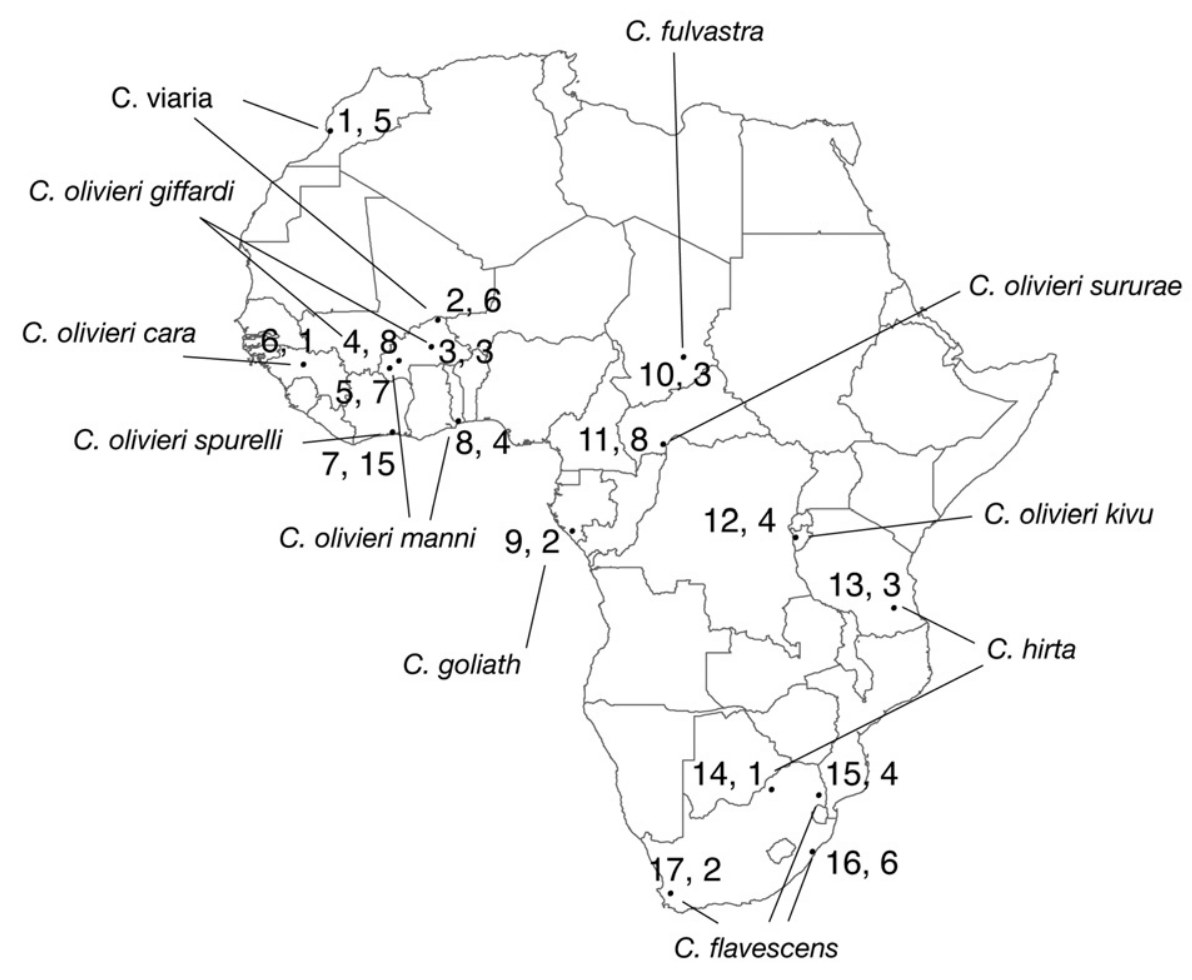

Fig. 1. Distribution of samples throughout Africa (locality number, number of samples). 1: Morocco, Massa; 2: Burkina Faso, Oursi; 3: Burkina Faso, Ouagadougou; 4: Burkina Faso, Bobo Dioulasso; 5: Burkina Faso, Banfora; 6: Guinea, Kazaouma; 7: Ivory Coast, Abidjan; 8: Togo, Lomé; 9: Gabon, Moueva; 10: Chad, Zakouma; 11: Republic of Central Africa, Bangui; 12: Burundi, Kigwena; 13: Tanzania, Ngaremba; 14: South Africa, Ellisras dist.; 15: Graskop dist.; 16: South Africa, Durban and 17: South Africa, Jonkershoek.

C6/683r, and $\mathrm{C} 3 / \mathrm{H} 15915$ or $580 \mathrm{~F} / \mathrm{H} 15915$ (see Table 2, Irwin et al. 1991; Dubey et al. 2006), and $c t r$ with the primer pairs L16517/H00651 or L16517/RCR2. PCR amplifications were carried out in a $25-\mu 1$ reaction volume containing $1.25 \mu \mathrm{l}$ of each of the primers, $2.5 \mu \mathrm{l}$ of Qiagen PCR buffer $10 \times, 0.25 \mu \mathrm{l}$ of $\mathrm{MgCl}_{2} 25 \mathrm{mM}$, $2 \mu \mathrm{dNTP} 2.5 \mathrm{mM}, 0.2 \mu \mathrm{l}$ Quiagen Taq DNA polymerase 5 units $/ \mu 1$, and $2 \mu \mathrm{l}$ of DNA from the extraction. Amplification conditions for the $c y t-b$ consisted of 35 thermal cycles of $30 \mathrm{~s}$ denaturing at $94{ }^{\circ} \mathrm{C}, 45 \mathrm{~s}$ annealing at $50^{\circ} \mathrm{C}\left(45^{\circ} \mathrm{C}\right.$ for the set $\left.580 \mathrm{~F} / \mathrm{H} 15915\right)$, and $1 \mathrm{~min}$ extension at $72^{\circ} \mathrm{C}$. Concerning the $c t r$, amplifications were made following the method described by Ehinger et al. (2002).

PCR products were then electrophoresed on a $1 \%$ agarose gel, visualized with ethidium bromide staining to verify PCR quality, and purified by centrifugal dialysis using the QIAquick PCR Purification Kit (Qiagen) according to manufacturer's instructions.

Cycle sequencing was performed in $10 \mu$ total volume containing $1-3 \mu \mathrm{l}$ of amplified DNA, $1 \mu \mathrm{l}$ of $10 \mu \mathrm{M}$ primer, and $4 \mu 1$ of ABI PRISM ${ }^{\mathrm{TM}}$ Dye Terminator 1
(Perkin-Elmer). Sequence reactions were visualized on an ABI 3100 genetic analyser (Applied Biosystems).

\section{Sequence analysis}

Nucleotide sequences of $c y t-b$ and $c t r$ sequences were edited with Sequence Navigator (Parker 1997) and aligned by eye. Three methods of phylogenetic analyses were carried out for the two genes using PAUP*version 4.0b10 PPC (Swofford 2001), and trees were rooted using sequences of two C. poensis (DQ305209 and DQ305210 for $c t r$, DQ305276 and DQ305277 for $c y t-b$ ) and one $C$. theresae (DQ305211 and DQ305278), which are genetically distant to the $C$. olivieri group (Maddalena 1990a). Tests were conducted on the total fragments (1241 base pairs (bp)). A neighbour joining (NJ) tree was constructed using Kimura two-parameter genetic distances (K2P; Kimura 1980). The maximum parsimony analyses (MP) were performed using the following options: heuristic search, 10 replicates of random addition of taxa, TBR branch swapping (Swofford 2001), all codon positions were equally 
Table 1. Descriptions of samples analyzed in this study, including species, sub-species, country of origin (ISO code), locality, collection number, and sample number

\begin{tabular}{|c|c|c|c|c|c|}
\hline Species & Sub-species & Country & Locality & Collection number & Sample number \\
\hline Crocidura flavescens & & $\mathrm{ZA}$ & Durban & IZEA-2349 & 1 \\
\hline Crocidura flavescens & & $\mathrm{ZA}$ & Durban & IZEA-2546 & 2 \\
\hline Crocidura flavescens & & $\mathrm{ZA}$ & Durban & IZEA-2547 & 3 \\
\hline Crocidura flavescens & & $\mathrm{ZA}$ & Durban & IZEA-2549 & 4 \\
\hline Crocidura flavescens & & $\mathrm{ZA}$ & Durban & IZEA-2582 & 5 \\
\hline Crocidura flavescens & & $\mathrm{ZA}$ & Durban & IZEA-2586 & 6 \\
\hline Crocidura flavescens & & $\mathrm{ZA}$ & Graskop dist. & GB-40552 & 7 \\
\hline Crocidura flavescens & & $\mathrm{ZA}$ & Graskop dist. & GB-40785 & 8 \\
\hline Crocidura flavescens & & $\mathrm{ZA}$ & Graskop dist. & GB-40786 & 9 \\
\hline Crocidura flavescens & & $\mathrm{ZA}$ & Graskop dist. & GB-40787 & 10 \\
\hline Crocidura flavescens & & $\mathrm{ZA}$ & Jonkershoek & GB-40564 & 11 \\
\hline Crocidura flavescens & & $\mathrm{ZA}$ & Jonkershoek & GB-40565 & 12 \\
\hline Crocidura fulvastra & & $\mathrm{TD}$ & Zakouma & MNHN-2000069 & 13 \\
\hline Crocidura fulvastra & & TD & Zakouma & MNHN-2000070 & 14 \\
\hline Crocidura fulvastra & & $\mathrm{TD}$ & Zakouma & MNHN-200065 & 68 \\
\hline Crocidura goliath & & GA & Moueva & MNHN-2001067 & 15 \\
\hline Crocidura goliath & & GA & Moueva & MNHN-2001096 & 16 \\
\hline Crocidura hirta & & $\mathrm{ZA}$ & Ellisras dist. & GB-40208 & 17 \\
\hline Crocidura hirta & & $\mathrm{TZ}$ & Ngarembe & MNHN-KP106 & 69 \\
\hline Crocidura hirta & & $\mathrm{TZ}$ & Ngarembe & MNHN-KP122 & 70 \\
\hline Crocidura hirta & & $\mathrm{TZ}$ & Ngarembe & MNHN-KP159 & 71 \\
\hline Crocidura olivieri & cara & GN & Kazaouma & MNHN-20030922 & 18 \\
\hline Crocidura olivieri & giffardi & $\mathrm{BF}$ & Bobo diulasso & IZEA-2503 & 19 \\
\hline Crocidura olivieri & giffardi & $\mathrm{BF}$ & Bobo diulasso & IZEA-2504 & 20 \\
\hline Crocidura olivieri & giffardi & $\mathrm{BF}$ & Bobo diulasso & IZEA-2505 & 21 \\
\hline Crocidura olivieri & giffardi & $\mathrm{BF}$ & Bobo diulasso & IZEA-2506 & 22 \\
\hline Crocidura olivieri & giffardi & $\mathrm{BF}$ & Bobo diulasso & IZEA-2507 & 23 \\
\hline Crocidura olivieri & giffardi & $\mathrm{BF}$ & Bobo diulasso & IZEA-3100 & 24 \\
\hline Crocidura olivieri & giffardi & $\mathrm{BF}$ & Bobo diulasso & IZEA-3101 & 25 \\
\hline Crocidura olivieri & giffardi & $\mathrm{BF}$ & Bobo diulasso & IZEA-3102 & 26 \\
\hline Crocidura olivieri & giffardi & $\mathrm{BF}$ & Ouagadougou & IZEA-3085 & 27 \\
\hline Crocidura olivieri & giffardi & $\mathrm{BF}$ & Ouagadougou & IZEA-3086 & 28 \\
\hline Crocidura olivieri & giffardi & $\mathrm{BF}$ & Ouagadougou & IZEA-3087 & 29 \\
\hline Crocidura olivieri & kivu & $\mathrm{BI}$ & Kigwena & IZEA-2732 & 30 \\
\hline Crocidura olivieri & kivu & $\mathrm{BI}$ & Kigwena & IZEA-3076 & 31 \\
\hline Crocidura olivieri & kivu & $\mathrm{BI}$ & Kigwena & IZEA-3078 & 32 \\
\hline Crocidura olivieri & kivu & $\mathrm{BI}$ & Kigwena & IZEA-3079 & 33 \\
\hline Crocidura olivieri & manni & $\mathrm{BF}$ & Banfora & IZEA-2492 & 34 \\
\hline Crocidura olivieri & manni & $\mathrm{BF}$ & Banfora & IZEA-2494 & 35 \\
\hline Crocidura olivieri & manni & $\mathrm{BF}$ & Banfora & IZEA-2495 & 36 \\
\hline Crocidura olivieri & manni & $\mathrm{BF}$ & Banfora & IZEA-2496 & 37 \\
\hline Crocidura olivieri & manni & $\mathrm{BF}$ & Banfora & IZEA-2497 & 38 \\
\hline Crocidura olivieri & manni & $\mathrm{BF}$ & Banfora & IZEA-2499 & 39 \\
\hline Crocidura olivieri & manni & $\mathrm{BF}$ & Banfora & IZEA-2500 & 40 \\
\hline Crocidura olivieri & manni & $\mathrm{TG}$ & Lome & IZEA-2351 & 41 \\
\hline Crocidura olivieri & manni & $\mathrm{TG}$ & Lome & IZEA-2352 & 42 \\
\hline Crocidura olivieri & manni & $\mathrm{TG}$ & Lome & IZEA-2353 & 43 \\
\hline Crocidura olivieri & manni & TG & Lome & IZEA-2355 & 44 \\
\hline Crocidura olivieri & spurelli & CI & Abidjan & IZEA-2404 & 45 \\
\hline Crocidura olivieri & spurelli & CI & Abidjan & IZEA-2672 & 46 \\
\hline Crocidura olivieri & spurelli & CI & Abidjan & IZEA-2673 & 47 \\
\hline Crocidura olivieri & spurelli & CI & Abidjan & IZEA-2392 & 48 \\
\hline Crocidura olivieri & spurelli & CI & Abidjan & IZEA-2406 & 49 \\
\hline Crocidura olivieri & spurelli & $\mathrm{CI}$ & Abidjan & IZEA-2553 & 50 \\
\hline Crocidura olivieri & spurelli & CI & Abidjan & IZEA-2762 & 51 \\
\hline Crocidura olivieri & spurelli & CI & Abidjan & IZEA-2365 & 52 \\
\hline
\end{tabular}


Table 1. (continued)

\begin{tabular}{|c|c|c|c|c|c|}
\hline Species & Sub-species & Country & Locality & Collection number & Sample number \\
\hline Crocidura olivieri & spurelli & $\mathrm{CI}$ & Abidjan & IZEA-2366 & 53 \\
\hline Crocidura olivieri & spurelli & $\mathrm{CI}$ & Abidjan & IZEA-2449 & 54 \\
\hline Crocidura olivieri & spurelli & $\mathrm{CI}$ & Abidjan & IZEA-2465 & 55 \\
\hline Crocidura olivieri & spurelli & CI & Abidjan & IZEA-2467 & 56 \\
\hline Crocidura olivieri & spurelli & CI & Abidjan & IZEA-2361 & 57 \\
\hline Crocidura olivieri & spurelli & CI & Abidjan & IZEA-2362 & 58 \\
\hline Crocidura olivieri & spurelli & $\mathrm{CI}$ & Abidjan & IZEA-2363 & 59 \\
\hline Crocidura olivieri & sururae & $\mathrm{CF}$ & Bangui & IZEA-2570 & 60 \\
\hline Crocidura olivieri & sururae & $\mathrm{CF}$ & Bangui & IZEA-2765 & 61 \\
\hline Crocidura olivieri & sururae & $\mathrm{CF}$ & Bangui & IZEA-2766 & 62 \\
\hline Crocidura olivieri & sururae & $\mathrm{CF}$ & Bangui & IZEA-2802 & 63 \\
\hline Crocidura olivieri & sururae & $\mathrm{CF}$ & Bangui & IZEA-2804 & 64 \\
\hline Crocidura olivieri & sururae & $\mathrm{CF}$ & Bangui & IZEA-2807 & 65 \\
\hline Crocidura olivieri & sururae & $\mathrm{CF}$ & Bangui & IZEA-2821 & 66 \\
\hline Crocidura olivieri & sururae & $\mathrm{CF}$ & Bangui & IZEA-3077 & 67 \\
\hline Crocidura viaria & & MA & Massa & IZEA-2616 & 72 \\
\hline Crocidura viaria & & MA & Massa & IZEA-2619 & 73 \\
\hline Crocidura viaria & & MA & Massa & IZEA-2620 & 74 \\
\hline Crocidura viaria & & MA & Massa & IZEA-5071 & 75 \\
\hline Crocidura viaria & & MA & Massa & IZEA-7804 & 76 \\
\hline Crocidura viaria & & $\mathrm{BF}$ & Oursi & IZEA-3108 & 77 \\
\hline Crocidura viaria & & $\mathrm{BF}$ & Oursi & IZEA-3110 & 78 \\
\hline Crocidura viaria & & $\mathrm{BF}$ & Oursi & IZEA-3111 & 79 \\
\hline Crocidura viaria & & $\mathrm{BF}$ & Oursi & IZEA-3118 & 80 \\
\hline Crocidura viaria & & $\mathrm{BF}$ & Oursi & IZEA-3327 & 81 \\
\hline Crocidura viaria & & $\mathrm{BF}$ & Oursi & IZEA-3331 & 82 \\
\hline
\end{tabular}

weighted. For maximum likelihood (ML) analyses, likelihood ratio tests, implemented with the computer program Modeltest 3.06, were first used to choose the mutation model that best fitted the data, according to the protocol of Posada and Crandall (1998).

The $\mathrm{TVM}+\mathrm{I}+\mathrm{G}$ model was selected with base frequencies $\quad(A=0.3043, \quad C=0.2437, \quad G=0.1455$, $\mathrm{T}=0.3065)$ estimated from the data, an unequal distribution of rates at variable sites $(\gamma=0.7560)$, and five different substitution types (rate $[\mathrm{A}-\mathrm{C}]=0.5207$, rate $[\mathrm{A}-\mathrm{G}]=[\mathrm{C}-\mathrm{T}]=14.8806$, rate $[\mathrm{A}-\mathrm{T}]=2.1171$, rate $[\mathrm{C}-\mathrm{G}]=1.4770$, rate $[\mathrm{G}-\mathrm{T}]=1.0000)$. ML analyses were then performed assuming this model with the program PhyML version 2.4.4. (Guindon and Gascuel 2003), which enables a dramatic reduction of computing time and a greater likelihood maximization ability. Bootstrap support values were obtained with 1000

Table 2. Primers designed in our laboratory

\begin{tabular}{ll}
\hline Primer name & Sequence $\left(5^{\prime}-3^{\prime}\right.$ direction $)$ \\
\hline $683 \mathrm{R}$ & CCA CCA CAT ATT AAA CCA GA \\
$231 \mathrm{~F}$ & ATT TGC AGT AAT GGC CAC CG \\
$580 \mathrm{~F}$ & ACT ATA TTA TCC TCA CTA G \\
RCr2 & GTG AAC ACG TGT GTG AAC ACG \\
\hline
\end{tabular}

pseudoreplicates for MP, NJ analysis, and 10 random replicates for stepwise addition of sequences, using PAUP*version 4.0b10 PPC (Swofford 2001). Bootstrap supports for ML analysis were obtained with 1000 pseudoreplicates using the program PhyML version 2.4.4. (Guindon and Gascuel 2003).

Nucleotide diversity $(\pi)$ was estimated using the DnaSP program version 4.10.3 (Rozas et al. 2005). The population genetic structure was determined by an analysis of molecular variance (AMOVA), available in Arlequin version 2.0 (Schneider et al. 2002). This analysis was performed at two different hierarchical levels: among clades and within clades. The K2P genetic distance between and within groups was calculated using the software Mega version 2.1 (Kumar et al. 2001).

\section{Results}

\section{Cyt-b and ctr}

The 85 individuals analysed in this study exhibit 64 different haplotypes for the whole sequence $(c y t-b+c t r$ : $1241 \mathrm{bp}$ ), of which 421 variable sites were found and 364 were parsimony informative. As the three phylogenetic methods gave identical arrangements of the main 
branches, the relationship between haplotypes is given only for the ML analysis (Fig. 2). The GenBank accession numbers are DQ305145-DQ305211 for ctr and DQ305212-DQ305278 for $c y t-b$.

Four major clades were observed. The first, Clade A, is the most basal and includes the sample of C. hirta from South Africa and Tanzania (Fig. 3). The second, Clade B, includes all the samples of $C$. flavescens from South Africa, and is highly supported by bootstrap values (all values of $100 \%$ ). Clade C (bootstrap values of $100 \%$ ) includes two samples of $C$. goliath from Gabon, and is a close relative to Clade D (bootstrap values $>93 \%$ ), which covers a large region from North and West Africa to Central Africa. Clade D is represented by six sub-species of $C$. olivieri from eight localities, $C$. viaria from $\mathrm{BF}$ and Morocco, and C. fulvastra from Chad.

This clade (D) is divided into eight sub-clades (I-VIII), supported by reasonable bootstrap values (for sub-clades II-IV and VI-VIII, bootstrap values $>81 \%$; for sub-clades $\mathrm{V}$, bootstrap values $>53 \%$ ). The northern (VIII) sub-clade includes the samples of C. viaria from $\mathrm{BF}$ and Morocco as well as the samples of C. fulvastra. Sub-clades I and II from the Central African Republic are represented by samples of C. olivieri sururae. Sub-clade III in East Africa is represented by samples of $C$. olivieri kivu. In western Africa the situation is more complex. First, we have subclade V with samples of $C$. olivieri cara from Guinea, C. olivieri spurelli from the Ivory Coast, C. olivieri manni from Banfora, BF, and C. olivieri giffardi from Bobo Dioulasso (BF). Second, we have sub-clade IV, which includes samples of $C$. olivieri manni from Togo and C. olivieri giffardi from Bobo Dioulasso and Ouagadougou (BF). Finally, we have two sub-clades (VI and VII) from Bobo Dioulasso, represented by samples of C. olivieri giffardi. Consequently, the samples from Bobo Dioulasso belong to four different sub-clades.

\section{Cyt-b genetic distances}

Mean genetic distances (K2P) between clades vary from $4.97 \%$ (C vs. D) to 11.83 (B vs. D) (Table 3), while mean genetic distances within clades vary from $0.26 \%$ (C) to $4.12 \%$ (A). Mean genetic distances between subclades of Clade D vary from $0.99 \%$ (V vs. VI) to $3.93 \%$ (I vs. VIII), while mean genetic distances within subclades vary between $0 \%$ (VII) and $1.71 \%$ (VIII).

\section{Discussion}

Our investigation was based on sampling coverage of a large part of Africa except from Egypt to Kenya. The results revealed the monophyly of the $C$. olivieri group
$(2 N=50)$, as previously demonstrated by Maddalena (1990a) from allozyme studies, and a remarkable distinction between four major clades (mean K2P distances between clades: $4.97-11.83 \%$ ). The clades are geographically distinct, representing different biomes, and appear to confirm the existence of at least three monophyletic taxa in the African giant shrew group: C. hirta Peters, 1852 (Clade A) from southern and eastern Africa (Miombo woodland); C. flavescens (Geoffroy, 1827) (Clade B) from southern Africa (southern savannas and fine bush), showing a different fundamental number of chromosomes ( $\mathrm{NF}=74$ vs. 66); and $C$. goliath (Thomas, 1906) from equatorial rain forest regions (Clade C). Considering C. olivieri (Lesson, 1827), C. viaria (Geoffroy, 1834), and C. fulvastra (Sundevall, 1843) the situation is more complicated. In fact, these species all belong to Clade D, which is subdivided into eight sub-clades (mean K2P distances between sub-clades: 1-3.9\%) with undefined interrelationships. All sub-clades are constituted by subspecies of $C$. olivieri except the last one (VIII), which includes only samples of $C$. viaria and $C$. fulvastra. The proximity of these two taxa is not surprising, as they share the same distribution in northern savannas (Sahelo-Sudanian region) and at the fringe of the Guineo-Congolese forest blocks, with $C$. viaria found in western areas and $C$. fulvastra in eastern areas.

We also note a genetic differentiation between the C. viaria populations of $\mathrm{BF}$ and Morocco (K2P: $2.36 \%$ ) that reflects the isolation of these species from the rest of Africa due to the Sahara desert. Concerning the other sub-clades (I-VII), they are distributed from Guinea to Burundi, with a hotspot in western areas where several sub-species of $C$. olivieri are mixed in the same clade, as manni (from BF), spurelli (from Ivory Coast), cara (from Guinea), and giffardi (from Bobo Dioulasso, BF) for sub-clade $\mathrm{V}$, and giffardi (from Bobo Dioulasso and Ouagadougou from BF) and manni (from Togo) for sub-clade IV, which share a large size as a common characteristic. We also note the presence of two other distinct sub-clades represented by the sub-species giffardi in Bobo Dioulasso. This unexpected diversity of sub-clades observed in western Africa, especially in $\mathrm{BF}$, is probably due to the high level of human activity in this part of the continent and the behaviour of C. olivieri, which is very commensal and commonly found in houses, food stores, markets, banana plantations, and farmlands as well as riverine habitats (Hutterer and Happold 1983). It is therefore likely that human activities have played a role in its dispersion.

Several studies of Soricidae show that the mean intraspecific genetic distances $(\mathrm{K} 2 \mathrm{P})$ for $c y t-b$ for the genus Sorex vary from $0 \%$ to $5.21 \%$ and interspecific distances from $1.32 \%$ to $21.7 \%$ (Fumagalli et al. 1999). Equivalent values for the genus Crocidura are $0.1-9 \%$ and 5.7-20.6\%, respectively (Vogel et al. 2003; Moto- 


\section{$M L$ \\ Bootstrap: MP}

NJ

- 5 changes

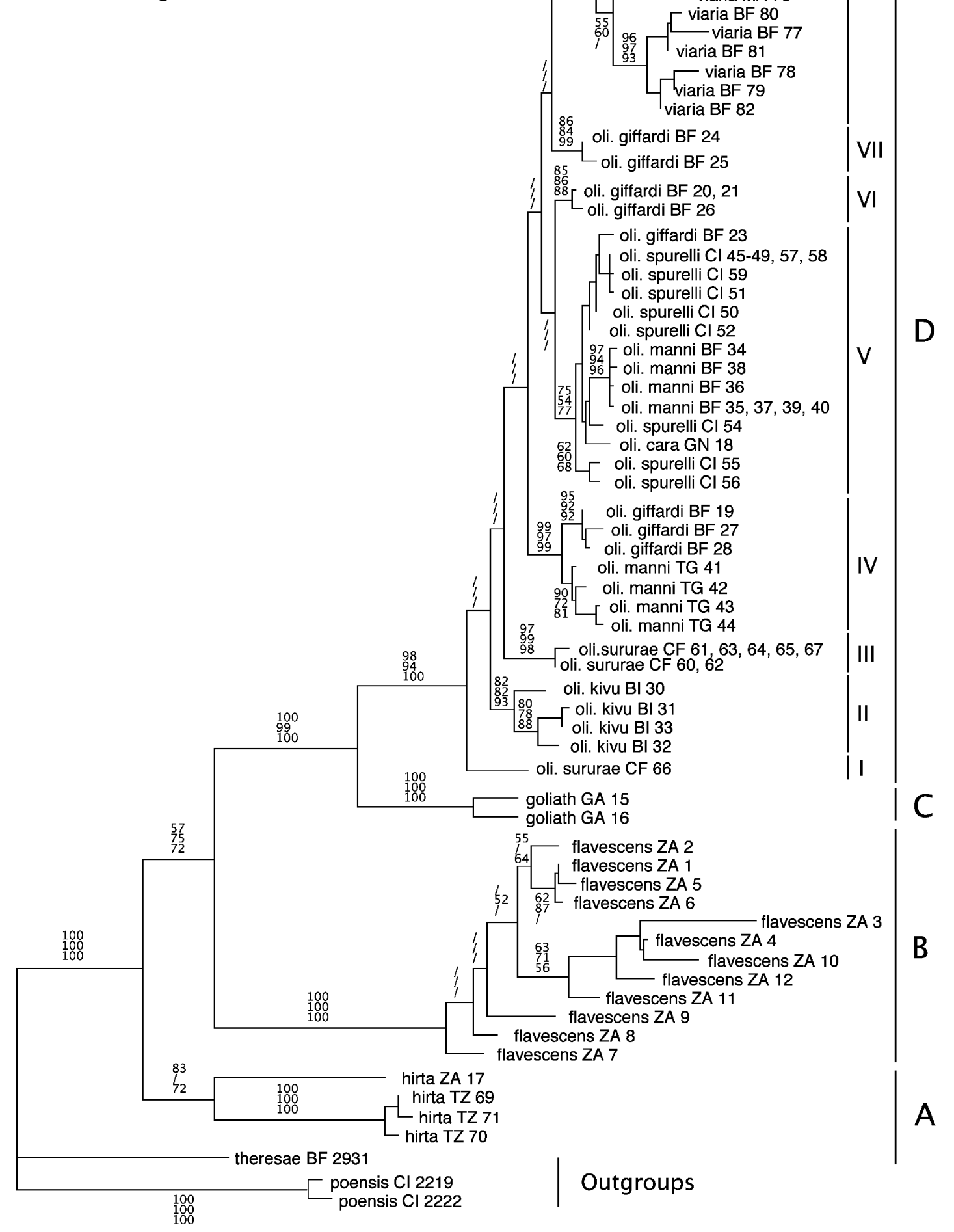

Fig. 2. Phylogeny of the $c y t-b+c t r$ fragments ( $1241 \mathrm{bp}$ ) analysed with maximum likelihood (ML) using the TVM $+\mathrm{I}+\mathrm{G}$ model of substitution and TBR branch swapping. Values in branches are bootstrap indices of support for the major branches for ML, maximum parsimony (MP), and distance (NJ) analyses (percentage of 1000 replications for each of the 10 random orders of stepwise addition of sequences). Codes are as in Table 1. 


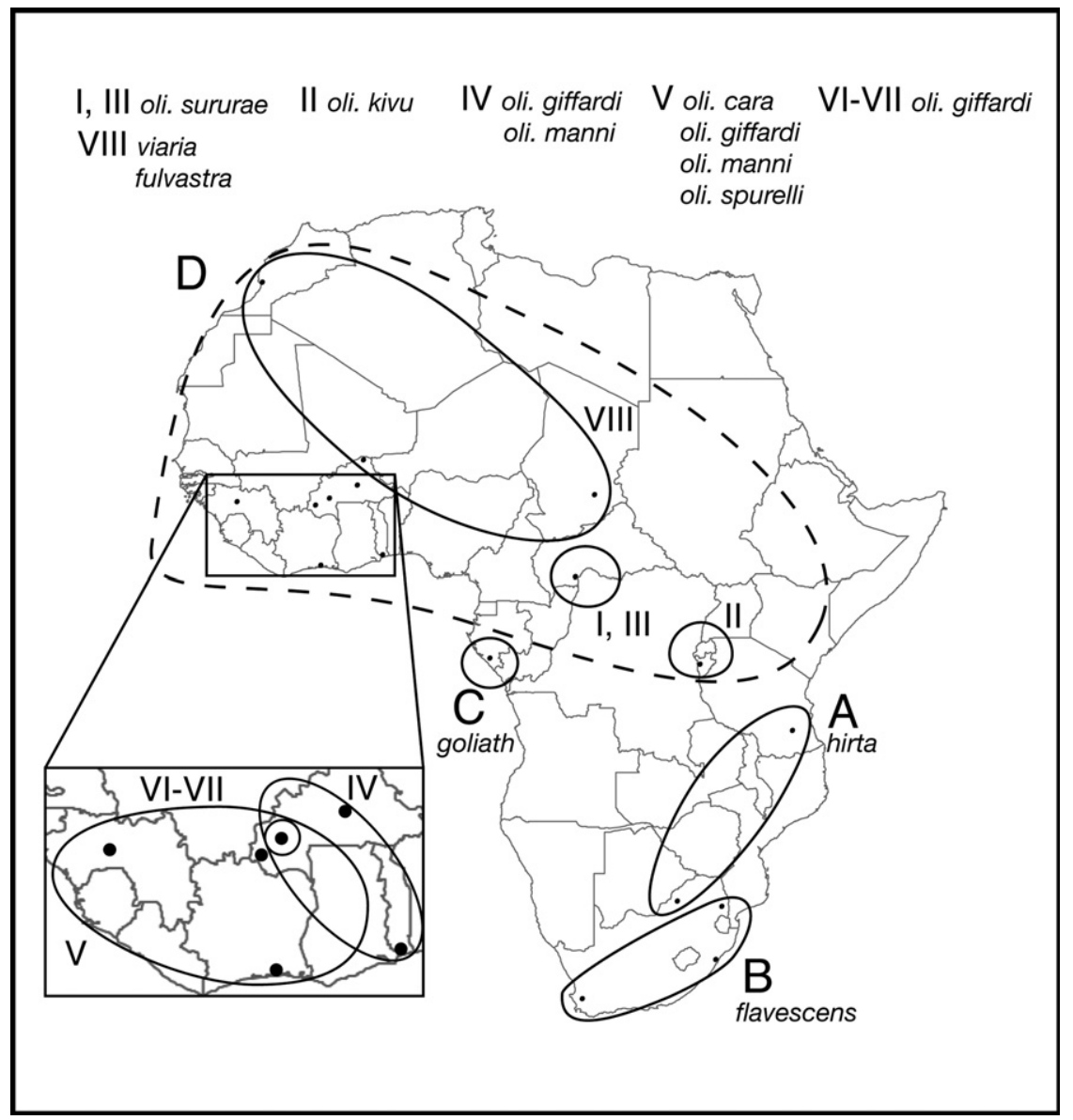

Fig. 3. Distributions of the different clades (A-D) and sub-clades (I-VIII).

kawa et al. 2000), and $0.48-3.51 \%$ and $7.73-10.7 \%$ for the genus Blarina (Brant and Orti 2002). In addition, based on the same gene and genetic distance, Bradley and Baker (2001) showed that genetic values between $2 \%$ and $11 \%$ had a high probability of being indicative of conspecific populations or valid species for rodents and bats, and therefore merit additional study concerning their specific status.

Thus, based on these previous studies and the large genetic distance (mean K2P between clades: $10.7-11.2 \%$ ) between the monophyletic taxa of Clades A-C, i.e., C. hirta, C. flavescens, and C. goliath, we accept the species assignments of these previous authors. In contrast, regarding Clade D, i.e., C. olivieri, $C$. fulvastra, and $C$. viaria, the small genetic distances (1-3.9\%) determined in our study do not enable us to state the level of differentiation. Consequently, we consider it premature to ascribe distinct species names to the different genetic populations of this clade. As in the Eurasian C. suaveolens group (Dubey et al. 2006), the only way to resolve this question is to study gene flow in the contact zones of the respective populations using both mitochondrial and nuclear markers.

Table 3. Mean $c y t-b$ genetic distances $(\mathrm{K} 2 \mathrm{P})$ between clades $(\mathrm{A}-\mathrm{D})$ and outgroups (Out1 = C. theresae, Out $2=$ C. poensis)

\begin{tabular}{llllll}
\hline & A & B & C & D & Out1 \\
\hline A & $\mathbf{0 . 0 4 1 9}$ & & & & Out2 \\
B & 0.1096 & $\mathbf{0 . 0 2 5 1}$ & & & \\
C & 0.1124 & 0.1142 & $\mathbf{0 . 0 0 2 6}$ & $\mathbf{0 . 0 3 0 6}$ & \\
D & 0.1110 & 0.1183 & 0.0497 & 0.1875 & 0.1165 \\
Out1 & 0.1647 & 0.1907 & 0.1873 & 0.2004 & $\mathbf{0 . 0 0 2 6}$ \\
Out2 & 0.1946 & 0.2038 & 0.1986 & & \\
\hline
\end{tabular}

Bold values in the diagonal column represent the genetic distance within clades. 


\section{Acknowledgements}

We thank G. Bronner and T. Maddalena for tissue samples, R. Cornette, C. Houssin, S. Moulin, E. Lecompte, L. Granjon, and V. Aniskine for fieldwork, Nelly Di Marco for laboratory facilities, R. Hutterer for the determination of C. fulvastra from Chad, and L. Fumagalli for scientific advice. Funding has been obtained from MNHN (BQR), CNRS UMR520, and Association Adrar des Iforas. In Tanzania, fieldwork was possible through the research project permit No. 2003-152-CC-2003-83, COSTECH and Dr. R. Makundi and R. Machangu (Pest Management Center, Sokoine University, Morogoro). In Chad, field assistance and permits were provided by the LZRV (Farcha) and Wildlife Department.

\section{References}

Bradley, R.D., Baker, R.J., 2001. A test of the genetic species concept: cytochrome- $b$ sequences and mammals. J. Mammal. 82, 960-973.

Brant, S.V., Orti, G., 2002. Molecular phylogeny of shorttailed shrews, Blarina (Insectivora: Soricidae). Mol. Phylogenet. Evol. 22, 163-173.

Butler, P.M., Thorpe, R.S., Greenwood, M., 1989. Interspecific relations of African crocidurine shrews (Mammalia: Soricidae) based on multivariate analysis of mandibular data. Zool. J. Linn. Soc. 96, 373-412.

De Hondt, H.A., 1974. Karyological studies on two insectivores of Egypt. Proc. Egypt. Acad. Sci. 25, 171-174.

Dubey, S., Zaitsev, M., Cosson, J.F., Abdukadier, A., Vogel, P., 2006. Pliocene and Pleistocene diversification and multiple refugia in a Eurasian shrew (Crocidura suaveolens group). Mol. Phylogenet. Evol. 38, 635-647.

Ehinger, M., Fontanillas, P., Petit, E., Perrin, N., 2002. Mitochondrial DNA variation along an altitudinal gradient in the greater white-toothed shrew, Crocidura russula. Mol. Ecol. 11, 939-945.

Fink, S., Excoffier, L., Heckel, G., 2004. Mitochondrial gene diversity in the common vole Microtus arvalis shaped by historical divergence and local adaptations. Mol. Ecol. 13, 3501-3514.

Fumagalli, L., Taberlet, P., Stewart, D.T., Gielli, L., Hausser, J., Vogel, P., 1999. Molecular phylogeny and evolution of Sorex shrews (Soricidae: Insectivora) inferred from mitochondrial DNA sequence data. Mol. Phylogenet. Evol. 11, 222-235.

Guindon, S., Gascuel, O., 2003. A simple, fast, and accurate algorithm to estimate large phylogenies by maximum likelihood. Syst. Biol. 52, 696-704.

Heim de Balsac, H., Aellen, V., 1958. Les Soricidae de basse Côte-d'Ivoire. Rev. Suisse Zool. 65, 921-956.

Heim de Balsac, H., Barloy, J.J., 1966. Révision des crocidures du groupe flavescens - occidentalis - manni. Mammalia 30, 601-633.

Heim de Balsac, H., Meester, J., 1977. Order Insectivora. Part 1. In: Meester, J., Setzer, H.W. (Eds.), The Mammals of
Africa: An Identification Manual. Smithsonian Institution Press, Washington, DC, pp. 1-29.

Hutterer, R., 1986. The species of Crocidura (Soricidae) in Morocco. Mammalia 50, 521-534.

Hutterer, R., 1993. Order Insectivora. In: Wilson, D.E., Reeder, D.M. (Eds.), Mammal Species of the World: A Taxonomic and Geographic Reference, second ed. Smithsonian Institution Press, Washington, DC, pp. 69-130.

Hutterer, R., 1994. Shrews of ancient Egypt: biogeographical interpretation of a new species. In: Merritt, J.F., Kirkland Jr., G.L., Rose, R.K. (Eds.), Advances in the Biology of Shrews. Carnegie Museum of Natural History Special Publication no. 18, pp. 407-414.

Hutterer, R., 2005. Order Soricomorpha. In: Wilson, D.E., Reeder, D.M. (Eds.), Mammal Species of the World: A Taxonomic and Geographic Reference, third ed. Johns Hopkins University Press, Baltimore, pp. 220-310.

Hutterer, R., Happold, D.C.D., 1983. The shrews of Nigeria (Mammalia: Soricidae). Bonn. Zool. Mon. 18, 1-79.

Hutterer, R., Tranier, M., 1990. The immigration of the Asian house shrew (Suncus murinus) into Africa and Madagascar. In: Peters, G., Hutterer, R. (Eds.), Vertebrates in the Tropics. Alexander Koenig Zoological Research Institute and Zoological Museum, Bonn, pp. 309-319.

Hutterer, R., Jones, G.S., Rossolimo, O.L., Van Gelder, R.G., Wang, S., 1982. Family Soricidae. In: Honacki, J.H., Kinman, K.E., Koeppl, J.W. (Eds.), Mammal Species of the World: A Taxonomic and Geographic Reference. Allen Press, Inc., Lawrence, pp. 67-102.

Irwin, D.M., Kocher, T.D., Wilson, AC., 1991. Evolution of the cytochrome- $b$ gene of mammals. J. Mol. Evol. 32, 128-144.

Kimura, M., 1980. A simple method for estimating evolutionary rate of base substitution through comparative studies of nucleotide sequences. J. Mol. Evol. 16, 111-120.

Kumar, S., Tamura, K., Jakobsen, I.B., Nei, M., 2001. MEGA2: molecular evolutionary genetics analysis software. Bioinformatics 17, 1244-1345.

Lekagul, B., McNeely, J.A., 1988. Mammals of Thailand. Darnsutha Press, Thailand.

Maddalena, T., 1990a. Systématique, évolution et biogéographie des musaraignes Afrotropicales et Paléarctiques de la sous-famille des Crocidurinae: une approche génétique. Thesis work, Université de Lausanne.

Maddalena, T., 1990b. Systematics and biogeography of Afrotropical and Palearctic shrews of the genus Crocidura (Insectivora: Soricidae): an electrophoretic approach. In: Peters, G., Hutterer, R. (Eds.), Vertebrates in the Tropics. Museum Alexander König, Bonn, pp. 297-308.

Maddalena, T., Mehmeti, A.M., Bronner, G., Vogel, P., 1987. The karyotype of Crocidura flavescens (Mammalia: Insectivora) in South Africa. Z. Säugetierkd. 52, 129-132.

Meylan, A., Vogel, P., 1982. Contribution à la cytotaxonomie des Soricidés (Mammalia: Insectivora) de l'Afrique occidentale. Cytogenet. Cell Genet. 34, 83-92.

Motokawa, M., Suzuki, H., Harada, M., Lin, L.K., Koyasu, K., Oda, S.I., 2000. Phylogenetic relationships among East Asian species of Crocidura (Mammalia, Insectivora) inferred from mitochondrial cytochrome $b$ gene sequences. Zool. Sci. 17, 497-504. 
Parker, S.R., 1997. Sequence navigator. Multiple sequence alignment software. Methods Mol. Biol. 70, 145-154.

Posada, D., Crandall, K.A., 1998. MODELTEST: testing the model of DNA substitution. Bioinformatics 14, $817-818$.

Quérouil, S., Hutterer, R., Barrière, P., Colyn, M., Kerbis Peterhans, J.C., Verheyen, E., 2001. Phylogeny and evolution of African shrews (Mammalia: Soricidae) inferred from 16s rRNA sequences. Mol. Phylogenet. Evol. 20, 185-195.

Quérouil, S., Barrière, P., Colyn, M., Hutterer, R., Dudu, A., Dillen, M., Verheyen, E., 2005. A molecular insight into the systematics of African Crocidura (Crocidurinae, Soricidae) using 16s rRNA sequences. In: Merritt, J.F., Churchfield, S., Hutterer, R., Sheftel, B.I. (Eds.), Advances in the Biology of Shrews II. International Society of Shrew Biologists, Special Publication no. 1, New York, pp. 99-113.
Rozas, J., Sanchez-DelBarrio, J.C., Messeguer, X., Rozas, R., 2005. DNA Sequence Polymorphism Version 4.10.2. Departament de Genetica. Universitat de Barcelona, Spain. Schneider, S., Roessli, D., Excoffier, L., 2002. Arlequin ver. 2.000: A Software for Population Genetic Data Analysis. Genetics and Biometry Laboratory, University of Geneva, Switzerland.

Swofford, D.L., 2001. PAUP* 4.0: Phylogenetic Analyses Using Parsimony (*and Other Methods). Beta version 4.0b10a for PC. Sinauer Associates, Inc., Publishers, Sunderland, MA.

Vogel, P., Maddalena, T., Aulagnier, S., 1988. The karyotype of Crocidura bolivari Morales Agacino, 1934 (Mammalia, Soricidae). Rev. Suisse Zool. 95, 779-783.

Vogel, P., Cosson, J.F., Jurado, L.F.J., 2003. Taxonomic status and origin of the shrews (Soricidae) from the Canary Islands inferred from a mtDNA comparison with the European Crocidura species. Mol. Phylogenet. Evol. 27, 271-282. 